\title{
COVID-19 and its impact on players' mental health
}

\author{
E. Paul Roetert ${ }^{\mathrm{a}}$, Lydia Bell \& Brian Hainline \\ aUnited States Tennis Association, New York, United States of America.
}

\section{ABSTRACT}

In the United States, collegiate sport is intimately tied to American Higher Education. In other words, National Collegiate Athletic Association (NCAA) student-athletes are first and foremost students, and the NCAA governance is interwoven with higher education governance. While the structure of typical student life may evolve over time, and while student-athletes, like other students who are pursuing passions beyond the traditional classroom and invest intensely in the development of their unique skills, being a student is and will continue to be an essential function of being a student-athlete.
Key words: COVID-19, mental, health, players.

Received: 1 May 2020

Accepted: 1 June 2020

Corresponding author: E. Paul Roetert, United States Tennis Association, White Plains, New York, United States of America, Email: proetert@ncaa.org

\section{INTRODUCTION}

COVID-19, a disease caused by the SARS-CoV-2 virus, has been classified as a pandemic by the World Health Organization-WHO (2020). As you are reading this article, NCAA members have begun preparing plans to resume college sports and return college athletes and staff to campus, as local and state governments and public health officials relax stay-at-home orders. In fact, the NCAA Sport Science Institute, in collaboration with an NCAA COVID-19 Advisory Panel composed of leading medical, public health and epidemiology experts has released specific action plan considerations to help colleges and universities mitigate risks of COVID-19 spread as staff and student-athletes return. Due to the size of the United States, every community can be very different, and schools may return to campus at different times. But each will have to balance the need to return with the top priority of protecting student-athlete health and well-being. Until there is a vaccine in place, medical experts recommend adopting specific practices, including hand sanitizing, cough/respiratory etiquette, physical distancing, universal masking when possible, testing and management plans mitigating spread if or when staff or students test positive for the coronavirus. In addition to the physical aspects of dealing with the pandemic, student-athletes also have had to adapt psychologically and emotionally to the stresses of new or different living and training conditions as well as re-socializing back in the schools setting. In fact, in preparation of returning to the school setting, the NCAA surveyed over 37,000 student-athletes, of which 1436 were tennis players, asking questions related to their well-being status (NCAA, 2020).

\section{WELL-BEING SURVEY}

The survey revealed that a majority of student-athletes surveyed reported experiencing high rates of mental distress since the outset of the COVID-19 pandemic. Over a third reported experiencing sleep difficulties, more than a quarter reported feeling sadness and a sense of loss, and 1 in 12 reported feeling so depressed it has been difficult to function, "constantly" or "most every day".

\begin{tabular}{|l|c|c|}
\hline & Men & Women \\
\hline Felt overwhelmed by all you had to do & $31 \%$ & $50 \%$ \\
\hline Experienced sleep difficulties & $31 \%$ & $42 \%$ \\
\hline Felt mentally exhausted & $26 \%$ & $39 \%$ \\
\hline Felt very lonely & $22 \%$ & $33 \%$ \\
\hline Felt a sense of loss & $21 \%$ & $31 \%$ \\
\hline Felt sad & $17 \%$ & $31 \%$ \\
\hline Felt overwhelming anxiety & $14 \%$ & $27 \%$ \\
\hline Felt overwhelming anger & $11 \%$ & $11 \%$ \\
\hline Felt things were hopeless & $11 \%$ & $16 \%$ \\
\hline $\begin{array}{l}\text { Felt so depressed that it was difficult to } \\
\text { function }\end{array}$ & $7 \%$ & $9 \%$ \\
\hline
\end{tabular}


Table 1. Mental Health Concerns During COVID-19 Pandemic (Percent of Participants Who Endorsed "Constantly" or "Most Every Day")

In most instances, the rates of mental health concerns were $150 \%$ to $250 \%$ higher than that historically reported by NCAA student-athletes in a previous survey (American College Health Association, 2018). Communication during the pandemic has been key to supporting student-athletes' mental and physical well-being. The data clearly indicated that many of the student-athletes felt significant mental stress in a variety of ways; however, $82 \%$ of respondents reported feeling positive or very positive about the support they have received from their coaches.

Coaching Tip: Based on the above findings, coaches need to be keenly aware of students' reliance on their support, particularly in these difficult times. If in-person interaction is not possible, consider social media check-ins on a regular basis when communicating remotely.

\section{ACADEMICS}

As a result of the pandemic, $99 \%$ of respondents said their coursework had shifted online. In the open-ended comment section, some student-athletes indicated they were struggling with the online format, others lacked the technology to be able to connect to their courses remotely, some shared that faculty had increased their assignment load as a result of moving online, and others reported struggling to connect with faculty, learning specialists or tutors when they had questions about course material.

Over $70 \%$ of participants indicated feeling positive about their ability to pass their spring courses, with a quarter feeling somewhat positive or somewhat negative and less than $5 \%$ feeling negative. However, fewer student-athlete respondents indicated feeling positive about their ability to keep up with classes (51\%). This needs to be considered as student-athletes showed strong interest in receiving a range of educational resources during the pandemic.

Coaching Tip: As it becomes increasingly likely that some, if not all, academic instruction in the U.S. will be online in 202021 , coaches may want to help students identify academic support personnel at the school year or semester's outset. Assessing internet connectivity and pointing students to technology resources (e.g. hotspot or laptop rental, discounted broadband, etc.) may help ameliorate academically related stresses later in the school year.

\section{LIVING ENVIRONMENT}

About $80 \%$ of student-athletes surveyed said they were living away from campus and with parents, family or a significant other. Nine percent were living with teammates or other friends, $4 \%$ were living alone and $3 \%$ remained in campus housing.

Nine of 10 student-athletes reported being in a stable housing situation and having access to enough food to meet their daily needs. While $80 \%$ reported knowing how to access a medical provider for physical health needs, $60 \%$ of men and $55 \%$ of women said they know how to access mental health support in their area. Those students living alone reported lower levels of agreement on all items.

Coaching Tip: Get to know your athletes and consider asking about their living situation, knowing that all are not the same. Some of these questions may be sensitive and studentathletes may not feel comfortable disclosing needs or concerns in a team setting, so check-ins both one and one as well as in a group setting may be helpful.

\section{TRAINING}

Of the athletes surveyed, 4 in 5 cited local regulations and a lack of access to appropriate facilities as barriers to their athletics training. In terms of resources specific to their training and physical well-being, respondents generally would look to coaches as their primary source of information. They also would turn to coaches to help maintain social connections.

\begin{tabular}{|l|c|}
\hline Barriers to Training & \\
\hline $\begin{array}{l}\text { Local regulations regarding travel, facility closures } \\
\text { and public gatherings }\end{array}$ & $83 \%$ \\
\hline Lack of access to appropriate facilities & $79 \%$ \\
\hline Lack of access to appropriate equipment & $72 \%$ \\
\hline Lack of access to training partners & $69 \%$ \\
\hline Lack of access to coaches & $50 \%$ \\
\hline Fear of exposure to COVID-19 & $43 \%$ \\
\hline Lack of motivation to train & $40 \%$ \\
\hline Family/personal responsibilities & $30 \%$ \\
\hline Too stressed or anxious to train & $21 \%$ \\
\hline Too sad or depressed to train & $13 \%$ \\
\hline $\begin{array}{l}\text { Table 2. Barriers to Training (Percent who } \\
\text { “Strong/y Agree, A// Participants) }\end{array}$ \\
\hline
\end{tabular}

In addition to structural barriers, participants also indicated that emotional barriers were impacting their ability to train, including a fear of exposure to COVID-19 (43\%), lack of motivation (40\%), feelings of stress or anxiety (21\%), and sadness or depression (13\%).

Coaching Tip: While access to athletics facilities will likely become more available, coaches may want to assess athletes' other concerns about returning to practice and competition. Bringing in a mental health professional may assist players in developing strategies to address stress and anxiety. More 
education about the virus, how it spreads and how other coaches and administrators are addressing key means of transmission of COVID-19 may be helpful.

RESOCIALIZATION STATUS

As rates of new infection begin to plateau and even decline in some countries, there is mounting enthusiasm for a resurrection of sport (Baggish et al, 2020). NCAA members have also begun preparing plans to resume college sports and return college athletes and staff to campus, as local and state governments and public health officials relax stay-at-home orders.

It is important to recognize that every community is different, and schools may return to campus at different times. But each will have to balance the need to return with the top priority of protecting student-athlete health and well-being. Until there is a vaccine in place, medical experts recommend adopting specific practices, including testing, masking and physical distancing when possible and having plans in place for stopping spread if and when staff or students test positive for the coronavirus.

Coaching Tip: Until a vaccine is in place, or until there is effective treatment, the most effective strategy to mitigate COVID-19 spread during resocialization includes the following: Physical distancing; universal masking when physical distancing is not possible; hand hygiene, especially after touching frequently used items or surfaces; using a tissue, or the inside of your elbow, to sneeze or cough into; not touching your face; disinfecting frequently used items and surfaces as much as possible; staying home if you feel sick and following the advice of your health care provider (NCAAb, 2020).

\section{CONCLUDING THOUGHTS}

The COVID-19 pandemic continues to impact athletes in multiple ways, but each athlete's living conditions and social context results in a unique experience. Health care providers have an important role in addressing the outcomes of the pandemic response (Pfefferbaum \& North, 2020). As a coach, this is very important to recognize since it is certainly possibly, even likely, that the virus will again force facility closures, move coursework online, and upend the routines of many players in the coming year. Also, these interruptions will be localized and their timing unpredictable. As we deal with the various COVID-19 related issues, coaches play an important role in the physical, psychological and emotional recovery of the players they coach. Getting to know athletes on and off the court and build trust early may make it easier to pinpoint their needs and connect them with resources should inperson contact with you, as a coach, as well as teammates again be prohibited. Finally, historically underrepresented or socially marginalized populations have been found to experience higher risks of infection and death, so you want to take that into account when working to understand your players' mindset in terms of return to play.

\section{REFERENCES}

American College Health Association. American College
Health Association-National College Health Assessment, Fall 2015, Spring 2016, Fall 2016, Spring 2017, Fall 2017 [data file]. Hanover, MD: American College Health Association [producer and distributor]; (2018-11-15).

Baggish, A., Drezner, J.A., Kim J., et al. (2020). Resurgence of sport in the wake of COVID-19: Cardiac considerations in competitive athletes. British Journal of Sports Medicine. Published Online First: 19 June

2020. doi: 10.1136/bjsports-2020-102516, https://doi.org/10.1136/bjsports-2020-102516

National Collegiate Athletic Association (2020a.). COVID-19 and its Impact on Mental Health. http://www.ncaa.org/about/resources/research/ncaastudent-athlete-covid-19-well-being-study

National Collegiate Athletic Association (2020b.). Resocialization of Collegiate Sport: Action Plan Considerations.

Pfefferbaum, B. \& North, C.S (2020). Mental Health and the Covid-19 Pandemic. New England Journal of Medicine. April 13, 2020. https://doi.org/10.1056/NEJMp2008017

World Health Organization. Be active during COVIDwww.who.int https://www.who.int/news-room/q-adetail/be-active-during-covid-19.

RECOMMENDED ITF TENNIS ACADEMY CONTENT (CLICK BELOW)

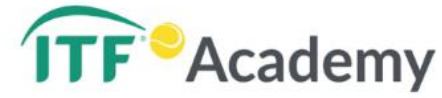

Copyright (c) 2020 E. Paul Roetert, Lydia Bell \& Brian Hainline

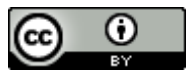

This text is under a Creative Commons BY 4.0 license

You are free to Share - copy and redistribute the material in any medium or format - and Adapt the content - remix, transform, and build upon the material for any purpose, even commercially under the following terms:

Attribution: You must give appropriate credit, provide a link to the license, and indicate if changes were made. You may do so in any reasonable manner, but not in any way that suggests the licensor endorses you or your use.

CCBY 4.0 license terms summary CCBY 4.0 license terms 